\title{
Devlet Arşivleri Cumhuriyet Arşivinde Bulunan 1931 ve 1962 Yılları Arasındaki Belgelerden Türkiye' de Görev Yaptıkları Belirlenen Yabancı Hemşireler *
}

\author{
Foreign Nurses that Worked in Turkey According to Documents of the Period Between 1931 and 1962 \\ Years of the Turkish State Archives Republic Archive
}

Fuat İnce ${ }^{i}$

¡ Dr. Öğr. Üyesi, Süleyman Demirel Üniversitesi Tıp Fakültesi Tıp Tarihi ve Etik AD., https://orcid.org/0000-0002-2887-7512

Öz

Amaç: Türkiye'de görev yapan yabancı hemşirelerle ilgili 1931 ve 1962 yılları arasındaki döneme ait arşiv belgelerini inceleyerek elde edilen bilgileri paylaşmaktır.

Yöntem: Çalışma için konuyla ilgili yayınlar okunmuş, Türkiye Cumhuriyeti Cumhurbaşkanlığı Devlet Arşivleri Başkanlığı Cumhuriyet Arşivi Kataloğunda tarama yapılmış ve bulunan arşiv belgeleri incelenmiştir.

Bulgular: İncelenen arşiv belgelerinden yabancı hemşirelerin Türkiye'de Cumhuriyet'in ilk yıllarından 1960'lara kadar hem hemşirelik eğitim kurumlarında hem de hastanelerde çalıştıkları görülmüştür. Arşiv belgelerinde isimleri geçen yabancı hemşire sayısı 26'dır. Bunlar Almanya, Avusturya, Amerika Birleşik Devletleri, Çekoslovakya ve Polonya uyruğundadırlar. İsimleri ise; Friyedel Üg, Sotto Kemma, Iles Yensen, Charlotte Keitel, Ella Bach, Else Schauman, Anna Haace, Margot Konrat, Elisabeth Sehulz, Hazel Avis Goff, Fransiska Karpeles, Marie Mochnacka, Grete Lindenbav, Miss Cecilia Sinclair, Miss Mag, Schweifert, Hilde Scromm, Katerina Thetter, Gertrud Sieber, Aenne Messerle, Hedwig Pfannes, Frances Bavons, Margot Henkel, Rosa Dotosch, Karin Duve ve Clara Anna Engle'dir.

Sonuç: İncelenen arşiv belgelerine göre yabancı hemşirelerin Türkiye'de hemşireliğin gelişiminde hem eğitim hem de hastane çalışmalarının düzenlenmesi açısından dolaylı katkılar sağladıklarını söylemek olanaklıdır.

Anahtar Kelimeler: Yabancı hemşireler, Cumhuriyet, Türkiye.

\section{ABSTRACT}

Aim: To share the information obtained by examining the archive documents for the period between 1931 and 1962 related to foreign nurses working in Turkey.

Method: For the study the publications related to the subject were read, Turkish Presidency State Archives Republic Archive Catalog was scanned and the archive documents were examined.

Results: It has been seen from the archive documents examined that in Turkey from the early years of the Republic to 1960 s the foreign nurses worked both of in the educational institutions and the hospitals. The number of foreign nurses mentioned in the archive documents of this period is 26. They are in the nationality of Germany, Austria, the United States of America, Czechoslovakia and Poland. Their names are; Friyedel Ug, Sotto Kemma, Iles Yensen, Charlotte Keitel, Ella Bach, Else Schauman, Anna Haace, Margot Konrat, Elisabeth Sehulz, Hazel Avis Goff, Fransiska Karpeles, Marie Mochnacka, Grete Lindenbav, Miss Cecilia Sinclair, Miss Mag, Schweifert, Hilde Scromm, Katerina Thetter, Gertrud Sieber, Aenne Messerle, Hedwig Pfannes, Frances Bavons, Margot Henkel, Rosa Dotosch, Karin Duve and Clara Anna Engle.

Conclusion: According to the archive documents examined, in the development of nursing in Turkey it is possible say that foreign nurses provided indirect contributions both of nursing education and organization of the hospital works.

Keywords: Foreign nurses, Republic, Turkey.

*Lokman Hekim Dergisi, 2020; 10 (3): 346-359

DOI: $10.31020 /$ mutftd.697180

e-ISSN: 1309-8004, ISSN 1309-761X

Geliş Tarihi - Received: 02 Mart 2020; Kabul Tarihi - Accepted: 07 Temmuz 2020

iletişim - Correspondence Author: Fuat ince <incefuat@gmail.com> 


\section{Giriş}

Hemşirelik geçmişten günümüze kendini sürekli yenileyen, bilimsel, teknolojik ve sosyokültürel değişimlere uygun olarak yenilenme sürecini her an devam ettiren, birey, aile ve toplum sağlığı ile ilgilenen uygulamalı bir sağlık disiplinidir. ${ }^{1}$ Hemşirelik yüzyıllar boyunca sadece kadınlara özgü bir meslek olarak bilinmekle birlikte artık erkeklerin de bu mesleğe hızlı bir geçiş süreci yaşanmaktadır. ${ }^{2}$ Bu durum hemşireliğin sağlığı geliştirme ve sürdürme ile hastalığı önleme ve hayat kalitesini artırma hedefleri dikkate alındığında son derece normaldir. ${ }^{3}$

Hemşirelik mesleğinin tarihsel kökenleri çok eskiye dayanmaktadır. ${ }^{4}$ Modern hemşireliğin kurucusu ise İngiliz Florence Nightingale'dir. ${ }^{5} 21$ Ekim 1853'te Osmanlı İmparatorluğu ile Rusya Çarlığı arasında savaş başlamıştır. 12 Mart 1854'te Ingiltere ve Fransa ile 1855 başında Piyemonte (Sardunya) Krallığının Osmanlının yanında savaşa girmesiyle Kırım Harbi ismini alan savaşta ${ }^{6}$ İstanbul'daki Selimiye Kışlasında Florance Nightingale ve yardımcılarının yaralı ve hasta askerlere yönelik tıbbi bakım faaliyetleri ilk modern hemşirelik uygulamalarıdır. ${ }^{7}$

1877-1878 Osmanlı-Rus, 1897 Osmanlı-Yunan, 1911-1912 Trablusgarp ve 1912-1913 Balkan Harpleri ile I. Dünya Savaşı'nda da yardım amaçı yurt dışından yabancı sağlık heyetleri gelmiştir. Bu heyetlerle gelen sağlık personeli arasında hemşireler de (şvester, sör, rahibe) yer almıştır. ${ }^{8}$ Osmanlı coğrafyasına bunların dışında misyonerlik faaliyetleri kapsamında da hemşireler (rahibeler) gelmiştir. ${ }^{9}$ Bunların yanı sıra Türk kadınları hastanelerde gönüllü olarak hasta ve yaralılarla ilgilenmişlerdir. ${ }^{10}$ Bunlar Türkiye'deki hemşirelik uygulamalarına örnek olarak gösterilebilecek birkaç faaliyet olarak sayılabilirler.

Türkiye'de ilk düzenli hastane hemşireliği 30 Aralık 1898'de açılan Gülhane Seririyat Hastanesi'nde başlamıştır. Alman Dr. Robert Rieder'in yönetimindeki hastanede Almanya'dan gelen hemşireler çalışmıştır. Bu hemşireler Türk hemşireliğinin şekillenmesinde, hemşirelik hizmetleri ve organizasyonu ile yönetiminde ilk örnekler olmuşlardır. ${ }^{11}$

Osmanlı coğrafyasında ilk hemşirelik eğitimi ise 1905 yılında Amerikalılar tarafından Beyrut'ta başlatılmıştır. XX. yüzyılın başında misyonerlik faaliyetlerini artırmış olan Amerikalılarca 1920 yılında İstanbul'da Amiral Bristol Amerikan Hastanesi bünyesinde bir hemşirelik okulu daha açılımıştır. ${ }^{8}$

Mekteb-i Tıbbiye-i Mülkiye (Tıp Okulu) bünyesindeki Hastabakıcı Kadın Mektebi 1910 yılında eğitime başlamıştır. Hilal-i Ahmer (Kızılay) Hastabakıcılık Mektebi ise Besim Ömer (Akalın) Paşa'nın çabalarıyla 1918 yılında açılmıştır. ${ }^{8}$

Türkiye'de 29 Ekim 1923 tarihinde Cumhuriyet ilan edildiğinde tüm sağlık personeli gibi hemşire sayısının da yetersiz olduğu anlaşılmıştır. ${ }^{12}$ Bu nedenle sağlıklı bir nesil yetiştirilmesi, kaliteli sağlık hizmeti sunulması, hastane ve nitelikli personel sayısının artırılması gibi hususlar Genç Cumhuriyet için en öncelikli konular arasında yer almışır. ${ }^{13}$

Hemşirelikle ilgili çabalar devam ederken bu alanda bir taraftan da yabancı hemşirelerden istifade edilmiştir. ${ }^{8}$ Türkiye 1933'te gerçekleştirdiği Üniversite Reformu ile birlikte Nazi rejiminden kaçan bilim insanları için adeta bir sığınak olmuştur. ${ }^{14}$ Incelenen belgelerden o dönemde sadece Yahudi asıllı hekimlerin ve diğer bilim insanlarının değil hemşirelerin de Türkiye'ye geldikleri anlaşılmıştır. Yabancı uyrukluların Türkiye'de ikamet etmeleri ve çalışmaları izne tabi olduğundan bu hemşireler için yasal izin belgeleri mahiyetinde evrak düzenlenmiştir. Günümüzde de 6283 Sayılı Hemşirelik Kanununda yer alan hükümlere uygun olarak hemşire unvanı almayanların ve bu kapsamda çalışma izni olmayan yabancıların Türkiye'de hemşirelik mesleğini icra etmeleri mümkün değildir. 
Bu çalışmanın amacı Cumhuriyet'in ilk yıllarından 1960'lı yıllara kadar Türkiye'ye gelip, düzenlenen Kararnamelerle belli sürelerle Türk hastanelerinde ve eğitim kurumlarında görev yapmalarına müsaade edilen yabancı hemşirelerin sağıı hizmetlerine katkılarını arşiv belgeleri ışığında değerlendirmektir.

\section{Yöntem}

Çalışma kapsamında konuyla ilgili kitaplar ve diğer yayınlar okunmuştur.

Türkiye Cumhuriyeti Cumhurbaşkanlığı Devlet Arşivleri Başkanlığı Cumhuriyet Arşivi Kataloğunda 2019 yıının Kasım ve 2020 yılının Mart ayları arasında yapılan tarama sonucunda konuyla ilgili bulunan belgeler incelenmiştir.

\section{Bulgular}

Cumhuriyetin kuruluşunda 1923'te zamanın Sıhhat ve İçtimai Muavenet Vekâleti (Sağlık Bakanlığı) bünyesinde yok denecek kadar az olan hemşire sayısı 1928'de 130'a, 1938'te 408'e, 1948'te 643'e, 1958'te $1.804^{\prime}$ e çıkmıştır. Hemşire başına düşen kişi sayısı ise $1928^{\prime}$ de $106.485,1938^{\prime}$ de 41.485 , 1948' de 30.983 ve 1958 ' de 14.402 olarak gerçekleşmiştir. ${ }^{15}$ Verilere bakıldığında hemşire sayısında düzenli bir artış ve hemşire başına düşen hasta sayısında da azalış olduğu görülmektedir. Ancak bunların yeterli olduğunu söylemek mümkün değildir. Bu nedenle Cumhuriyet'in ilk yıllarından itibaren hem mevcut hastanelerde hem de yeni açılan hastanelerde ve hemşirelik okullarında eğitimli yabancı hemşire istihdamı bir alternatif olarak uygulanmıştır. $^{8}$

Türkiye Cumhuriyeti Cumhurbaşkanlığı Devlet Arşivleri Başkanlığı Cumhuriyet Arşivinde bulunan belgelerin incelenmesi ile yabancı hemşireler hakkındaki tüm iş ve işlemlerin Hükümet Kararnameleri ile yapıldığı anlaşılmıştır. Bu hemşirelere ilişkin görevlendirmeler, çalışacakları yerler, alacakları maaşlar ve sözleşme süreleri Kararnamelerde detaylı bir şekilde belirtilmiştir.

Görevlendirmeleri içeren resmî belgeler Cumhurbaşkanlarınca onaylanmıştır. Gazi Mustafa Kemal Atatürk ve İsmet İnönü onaylı 13'er adet arşiv belgesi bulunmuştur. Celal Bayar onaylı Kararname sayısı yedi, Cemal Gürsel tarafından onaylanmış Kararname sayısı ise üçtür.

Yabancı hemşireler konusunda incelenen toplam 36 adet arşiv belgesinde ismi geçen hemşire sayısı 26 olarak tespit edilmiştir. Bunların 14'ü Almanya, beşi Avusturya, beşi Amerika Birleşik Devletleri (ABD), biri Çekoslovakya ve biri de Polonya uyruğundandır.

Alman hemşireler Friyedel Üg, Else Schauman, Anna Haace, Elisabeth Sehulz, Greta Lindenbav, Aenne Messerle, Hedwig Pfannes ve Karin Duve İstanbul'da, İles Yensen, Charlotte Keitel ve Ella Bach Ankara'da, Margot Konrat i̇zmir'de görev yapmışlardır. Margot Henkel'in görev yeri belirtilmemiş, İstanbul Yenibahçe Vakıf Gureba Hastanesine başhemşire olarak görevlendirilen Sotto Kemma ise ailevi nedenlerle görevine katılamamıştır.

Avusturyalı Gertrud Sieber ve Katerina Thetter İstanbul'da, Schweifert önce İzmir'de sonra İstanbul'da, Hilde Scromm Ankara'da ve Rosa Dotosch Sivas'ta çalışmışlardır.

Amerikalı hemşireler Hazel Avis Goff, Cecilia Sinclair, Miss Mag ve Frances Bavons İstanbul'da çalışmışlar, Clara Anna Engle ise İzmir'de görev yapmıştır.

Çekoslovak tebaasından Fransiska Karpeles'in görev yeri belirtilmemiştir.

Polonyalı hemşire Marie Mochnacka İstanbul'da çalışmıştır. 


\section{Gazi Mustafa Kemal Atatürk Döneminde Yabancı Hemşireler}

Bulunan arşiv belgelerinden Atatürk tarafından onaylanmış ilk Kararname 1 Şubat 1931 tarihlidir. Buna göre Almanya Barmen Kızılhaç Kurumu'ndan hemşire olarak mezun olduktan sonra bir süre İstanbul'daki özel kliniklerde çalışmış olan Alman uyruklu Friyedel Üg'e İstanbul'daki sağlık kurumlarından birisinde hemşire olarak çalışması için izin verilmiştir. ${ }^{16}$

Incelenen ikinci belge de 1 Şubat 1931 tarihli olup, Alman tebaasından Sotto Kemma ile ilgilidir. Belgeye göre Sotto Kemma 1 Şubat 1931 tarihinden önce de Türkiye'de üç yıl süreyle çalışmıştır. Daha sonra Almanya'ya dönmüş ve Hamburg Ependorf Hastanesi'nde çalışmaya başlamıştır.1 Şubat 1931 tarihinden geçerli olmak üzere Yenibahçe Gureba Hastanesi'nde boş olan başhemşirelik görevine atanmıştır. ${ }^{17}$ Bununla birlikte 18 Mart 1931 tarihli başka bir arşiv belgesi incelendiğinde Sotto Kemma'nın ailece zuhur eden mazereti nedeniyle Türkiye'ye gelemediği anlaşılmıştır. Bu nedenle onun yerine Almanya'dan başka bir başhemşirenin getirtilmesine çalışılmıştır. ${ }^{18}$

18 Mayıs 1931 tarihli belgeye göre ise Ankara Numune Hastanesi'nde çalışan Alman uyruklu iles Yensen'in 21 Haziran 1931 tarihinde sona eren sözleşmesi bu tarihten itibaren 2 yıl süreyle tekrar uzatılmıştır. ${ }^{19}$ Ayrıca 23 Mayıs 1933 tarihli Kararname ile İles Yensen'in 20 Haziran 1933 tarihinde bitecek sözleşmesi iki yıl müddetle bir kez daha uzatılmıştır. ${ }^{20}$

7 Haziran 1931 tarihli bir başka Kararnameyle Ankara Numune Hastanesi'nde başhemşire olarak görev yapan Alman tebaasından Charlotte Keitel'in 13 Mart 1931 tarihinde sona eren sözleşmesi 2 yıl, aynı hastanede hemşire olarak görev yapan Ella Bach'ın süresi de 21 Haziran 1931 tarihinden itibaren iki yıl daha uzatılmıştır. ${ }^{21}$

Alman uyruklu bir başka hemşire olan Else Schauman ile ilgili belge 14 Eylül 1931 tarihlidir. Schauman'ın Almanya'daki hemşirelik sınavından başarıyla geçtiği ve çeşitli kurumlarda çalışarak iyi vesikalar aldığı, daha önce Burgaz Sanatoryumunda bir yıl çalıştığı ve bu sayede biraz Türkçe öğrendiği belirtilmiştir. 90 Lira ücretle ve üç sene süreyle İstanbul Gureba Hastanesine atamasının yapılması kararlaştırılmıştır. ${ }^{22}$ incelenen bu belgeden, daha önce 18 Mart 1931 tarihli Kararnamede Türkiye'ye gelemeyeceği belirtilen Sotto Kemma'nın yerine Else Schuman ile sözleşme yapıldığı anlaşılmıştır.

Bir diğer arşiv belgesi 2 Mart 1932 tarihli olup, Alman hemşire Anna Haace ile ilgilidir. Heybeliada Sanatoryumunda çalışmakta olan Anna Haace'nin sona eren mukavelesi üç yıl süreyle uzatılmıştır. ${ }^{23} 1930$ 'lu yıllarda Sanatoryumda başhemşire olarak çalışan Anna Haace personelin eğitimi ve tıbbi bakım hizmetlerindeki disiplinli çalışmaları dikkat çekmiştir. ${ }^{24}$

9 Ekim 1932 tarihli arşiv belgesine göre Doğum ve Çocuk Bakımevleri genel kadrosunda başhemşire pozisyonunda bulunan bir yabancı hemşirenin Ağustos 1932'de mukavelesi sona erdikten sonra memleketine döndüğü belirtilmiştir. Belgede isim ve ülke bilgileri belirtilmeyen bu hemşirenin yerine onunla aynı nitelikleri taşıyan bir Türk hemşirenin başhemşire kadrosuna atanması kararlaştırı Imıştır. Maaşı $60 \mathrm{TL}$, görev yeri ise Konya Doğum ve Çocuk Bakımevi olarak belirlenmiştir. ${ }^{25}$

Alman hemşire Margot Konrat hakkında bulunan ilk belge 11 Ekim 1934 tarihlidir. İncelenen belgeye göre Konrat daha önce İzmir Eşrefpaşa Hastanesinde çalışmış ve buradaki hizmetinden memnun kalınmıştır. Bu

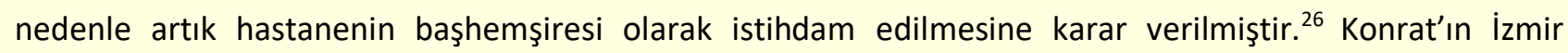
Eşrefpaşa Hastanesi'nde daha önceki görevi ile ilgili bilgiye ulaşılamamıştır. Ancak sona eren sözleşmesi 29 Kasım 1936 tarihinden itibaren 4 Ocak 1937 tarihli başka bir Kararname ile iki yıl daha uzatılmıştır. ${ }^{27}$

İncelenen 1 Ocak 1935 tarihli belgeye göre İstanbul'da bulunan Lübeck Kızılhaç Hastanesi'nden çıkan Elisabeth Sehulz'un üç yıl için Cerrahpaşa Hastanesi yabancı başhemşireliğinde çalıştırılmasına karar 
verilmiştir. ${ }^{28}$ Arşiv belgesinde Elisabeth Sehulz'un uyruğu belirtilmemekle birlikte, kendisi için kullanılan schewestr unvanından, isminden ve Lübeck Kızılhaç Hastanesinde görev yapmış olması nedeniyle Alman tebaasından olduğu anlaşılmıştır.

Atatürk dönemindeki 13 Mayıs 1936 tarihli belge Miss Goff ile ilgilidir. Bu belge hemşireliğin eğitim kısmı ile ilgili olarak çalışmada yer alan ilk belgedir. Buna göre Amerikalı hemşire Miss Goff, İstanbul'daki Kızılay Hastabakıcı Hemşireler Mektebinin geliştirilmesi ve ilerletilmesi için bu okulun yöneticisi olarak atanmıştır. Sözleşme süresi üç yıl, aylık maaşı ise her ayın başında nakit ve kambiyo borsasındaki rayici üzerinden 300 Doların Türk Lirası karşılığı olacak şekilde belirlenmiştir. ${ }^{29}$ Hazel Avis Goff, 1939 yılında görev süresi dolduktan sonra ayrılmış, yerine Haydar Kermen vekaleten müdür olarak atanmıştır. ${ }^{30}$

Bu döneme ait incelenen belgelere göre İstanbul'da çalışan Alman hemşireler; Friyedel Üg, Sotto Kemma, Else Schauman, Anna Haace ve Elisabeth Sehulz'dur. Amerikalı hemşire Miss Goff da İstanbul'da çalışmıştır. Ankara'da çalışanlar ise Alman tebaasından iles Yensen, Charlotte Keitel ve Ella Bach'tır. Yine Alman uyruğundan olan Margot Konrat ise İzmir'de çalışmıştır.

Atatürk dönemindeki belgelerden ilki olan 1 Şubat 1931 tarihli olan Friyedel Üg hakkındaki belge ile Miss Goff hakkındaki 13 Mayıs 1936 tarihli belge seçilen örnek arşiv belgeleri olarak aşağıda verilmiştir. (Şekil 1 ve 2)

\section{İsmet İnönü Döneminde Yabancı Hemşireler}

Bu döneme ait ilk belge 13 Ocak 1939 tarihlidir. Incelenen arşiv belgesine göre Çekoslovak tebaasından Yahudi asıllı Fransiska Karpeles'e çalışmak üzere iki yıl müddetle Türkiye'de oturmasına izin verilmiştir. Fransiska Karpeles'in Türkiye'de nerede çalıştığı ve ne kadar süreyle kaldığına dair başka belge bulunamamıştır. Fransiska Karpeles'le ilgili belgede Alman uyruklu Alfret Katza'nın da ismi geçmektedir. Ona da Türkiye'de çalışmak üzere bir yıl oturma izni verilmiştir. Ancak Alfret Katza hemşire olmayıp, dekorasyon uzmanıdır. ${ }^{31}$

22 Haziran 1939 tarihli arşiv belgesi ise Ankara'da açılacak Askerî Hasta Bakıcı Hemşireler Mektebi ile ilgilidir. ${ }^{32}$ Bu dönemde hemşirelik, hastabakıcı-hemşire veya sadece hastabakıcı olarak ifade edilmiştir. 3017 Sayılı Sıhhat ve İçtimai Muavenet Vekâleti Teşkilât ve Memurin Kanununda ve diğer mevzuatta hastabakıcıhemşire tabiri yer almıştır. Bu nedenle askerî hemşire okulunun adı da Askerî Hastabakıcı Hemşireler Mektebi olarak konulmuştur. Bununla birlikte Asker Hastaneleri İdare Talimatında hemşire kavramı tek başına ifade edilerek hemşirelikle hastabakıcılık görevleri birbirlerinden ayrıştııılmıştır. ${ }^{33}$ Çalışmada yer alan bu her iki terimin de hemşire olarak anlaşılması gerekmektedir. İncelenen arşiv belgesine göre Askerî Hasta Bakıcı Hemşireler Mektebinde uygulamalı hasta bakımı eğitimi için 250 Lira maktu ücretle ABD veya Almanya'dan uzman hemşire öğretmen getirtilmesi kararlaştırılmıştır. ${ }^{32}$

Bir diğer arşiv belgesi 25 Ağustos 1939 tarihli olup, Marie Mochnacka ile ilgilidir. Ancak Mochnacka'nın, Marie'den önceki ilk ismi veya unvanı belgede silik olduğundan tam olarak okunamamıştır. İstanbul'daki Hastabakıcı Hemşireler Mektebi yöneticisi olan Amerikalı Hazel Avis Goff'un üç yıllık sözleşmesi sona erdikten sonra onun yerine Haydar Kermen'in vekâleten atandığından bahsedilmişti. İncelenen belgeye göre Goff'un yerine bu sefer Polonyalı Marie Mochnacka ile sözleşme yapılmasına karar verilmiştir. Kendisiyle 300 Lira aylık ücret karşılığında anlaşılmıştır. Sözleşme süresi üç yıldır. Ayrıca Varşova'dan İstanbul'a kadar geliş yol parasının da serbest dövizle kendisine ödenmesi kararlaştırılmıştır. ${ }^{34}$

İstanbul Üniversitesi (iü) Çapa Radyoloji Enstitüsü’nün başhemşiresi olan Yahudi asıllı Alman hemşire Greta Lindenbav'ın görev süresinin 31 Mayıs 1941 tarihine kadar uzatılmasını da içeren belgeye göre Greta Lindenbav'ın kardeşi Maks Lindenbav'a Türkiye'de oturma izni verilmiştir. ${ }^{35}$ 
T. C.

BAŞVEKALLET

MUAMELAT MUDCRLCGO

Sabs : 70.590

KARARNAME

1 mangada Barmen Saltbiahmex milessesestinien werm olug blx $x$ middettenberl Istambulda hususi kiniklexde galigmakta olam Almam

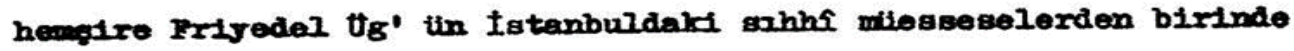

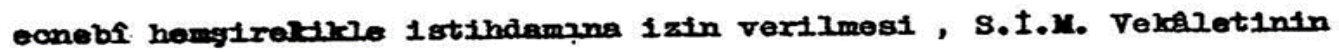
I2/I/93I tarin ve IO numarall terkeresijle yapilan teklifi ve Mal1je Vekaletinin $28 / 1 / 931$ tarih ve $\frac{\text { bitce }}{1216 / 69}$ numaralz miltaleansmeal $x$ userine Icra Vekillerl Heyetinin I/2/9SI tarihli Igtimainda tasvip ve kabul olummagtir.

$I / 2 / 951$

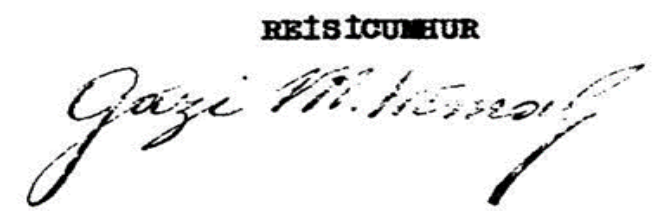

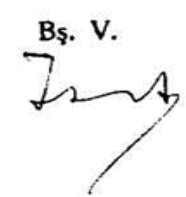

Da. v.

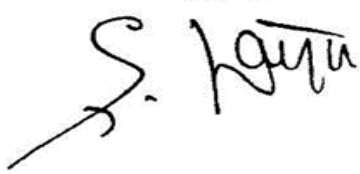

Ad. $v$.

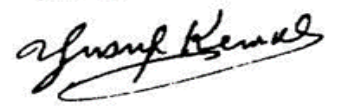

M. M. V.

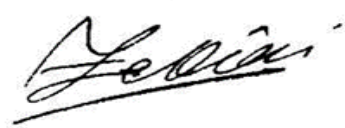

Ha. v.
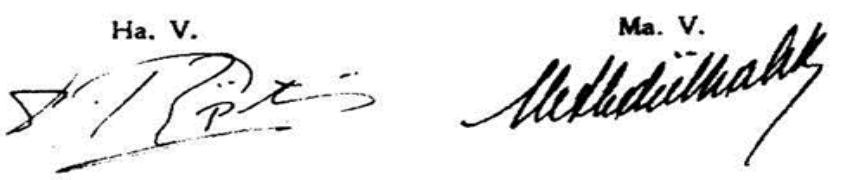

Ik. $v$.

S. I. M. v.

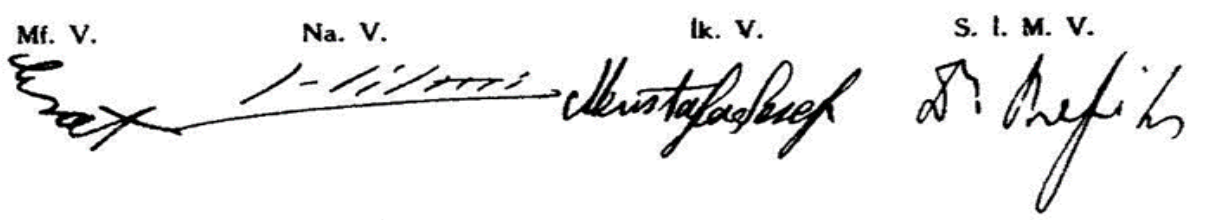


T. C.

BASVEKALET KARARLAR MODORLOGO

$$
\text { C* BASARANLIR }
$$

Karamame

$$
\begin{gathered}
\text { Kesar ayreas } \\
2 \\
4578
\end{gathered}
$$

Kazilay Cemiyetince Istanbulda tesis ve idare edilmekte olan Hasta Bakıcı Hemşireler Mektebinin intiyaca uygun bir surette terakki ve Inkişafınl teminen §̧imalf Amerika tebaasından Miss Goff'un, 300 doların her ay başı nakit ve kamblyo borsasindaki rayjci tuerinden plurk parası aylik ticretle vo tiç sene middetle mezkûr hasta bakıeılik mekte-

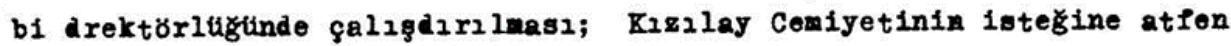
ialiye Vekillifinin I2/5/936 tarih ve 54248/6554 sayll tezkeresi ifzerine tcra Vekilleri Heyetince I3/5/936 da onanmegirx.

$$
\text { I3/5/936 }
$$

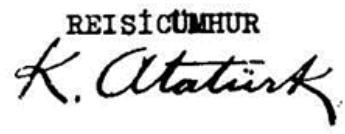

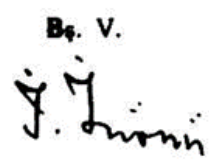
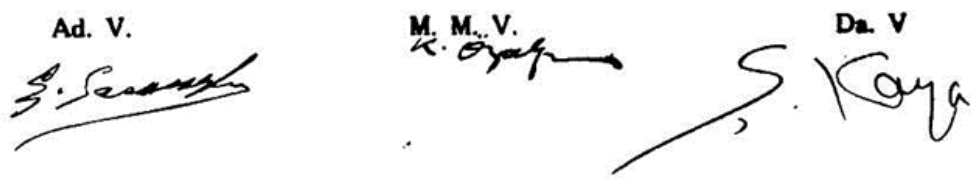

Ha. V. V.

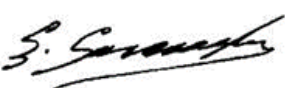

ik. $v$. c. 9027
Ma. V.<smiles>CC(C)(C)C1CCCC1</smiles>

Mf. v.<smiles></smiles>

G. 1. v.

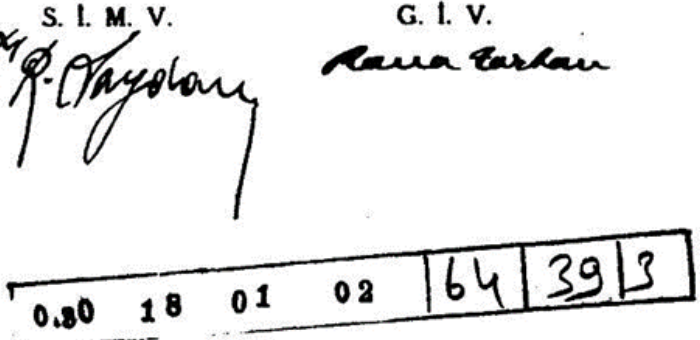

Na. V.
A. Coelinkaya

Zr. V.

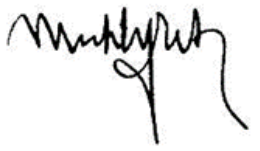

Şekil 2. 13 Mayıs 1936 tarihli Miss Goff hakkındaki belge 
Atatürk döneminde hakkında 11 Ekim 1934 ve 4 Ocak 1937 tarihli iki kararname bulunan Margot Konrat ile ilgili İsmet İnönü dönemine ait üç belge daha bulunmuştur. Bunlardan 28 Eylül 1940 tarihli olan belgeye göre İzmir Eşrefpaşa Hastanesi Başhemşiresi olan Konrat'ın 28 Kasım 1940 tarihinde sona erecek olan mukavelesi iki yıl uzatılmıştır. ${ }^{36} 16$ Kasım 1942 tarihli Kararname ile 28 Kasım 1942 tarihinden itibaren iki yıl daha aynı hastanede çalışmasına izin verilmiştir. ${ }^{37} 14$ Aralık 1944 tarihli belgeye göre ise Konrat'ın 28 Kasım 1944 tarihinden itibaren iki yıl daha İzmir Eşrefpaşa Hastanesinde çalışması uygun bulunmuştur. ${ }^{38}$

Yukarıda adı geçen Polonyalı hemşire Mochnacka sözleşmesi süresi dolduktan sonra Kızılay Hastabakıcı Hemşireler Mektebinden ayrılmış ve Esma Deniz vekâleten müdür olarak görevlendirilmiştir. Amerikalı Miss Cecilia Sinclair 1945 yılında okula asli müdür olarak gelmiş ve bu görevi 1948 yılına kadar sürdürmüştür. ${ }^{33}$ İncelenen 5 Mayıs 1947 tarihli belgeye göre müdür Miss Sinclair ve aynı okulda öğretmen olan Miss Mag'in 1 Eylül 1946 tarihinden itibaren yurtdışına döviz çıkarmalarına izin verilmiştir. Sinclair'in çıkaracağı miktar 150 Dolar, Mag'in 100 Dolar olarak belirlenmiştir. ${ }^{39}$

Avusturyalı hemşireler Schweifert ve Hilde Scromm ile ilgili belge 25 Mayıs 1948 tarihlidir. Bunlardan Schweifert'in İzmir Doktor Behçet Uz Hastanesinde ve Hilde Scromm'un Ankara Numune Hastanesinde iki yıl süreyle çalışmalarına izin verilmiştir. ${ }^{40}$

2 Haziran 1948 tarihli bir başka belgeye göre Avusturyalı Katerina Thetter'in Heybeliada Verem Sanatoryumunda iki yıl süreyle çalıştırılması kararlaştırılmıştır. ${ }^{41}$ Thetter de tıpkı 1930'larda aynı sanatoryumda başhemşire olarak görev yapan Alman Anna Haace gibi başarılı çalışmalarıyla dikkat çekmiştir. ${ }^{24}$

18 Nisan 1949 tarihli belgeye göre ise Avusturya uyruğundan Gertrud Sieber iü Tıp Fakültesi Dış Hastalıkları Kliniğinde hemşire olarak çalışmıştır. ${ }^{42}$

Aenne Messerle ile ilgili belge 13 Ekim 1949 tarihlidir. Alman uyruğundan olan bu hemşire iü Tıp Fakültesi Birinci Cerrahi Kliniğinde ameliyat hemşiresi olarak çalışmıştır. ${ }^{43}$

2 Şubat 1950 tarihli belgeye göre ise Alman tebaasından Hedwig Pfannes iü Tıp Fakültesi ikinci Dış Hastalıkları Kliniğinde ameliyat hemşiresi olarak çalışmıştır. ${ }^{44}$

Cumhurbaşkanı İsmet İnönü döneminde Polonyalı Marie Mochnacka, Alman tebaasından Greta Lindenbav, Amerikalı Cecilia Sinclair ve Miss Mag, Avusturyalı Gertrud Sieber ve Katerina Thetter, Alman Aenne Messerle ve Hedwig Pfannes İstanbul'da çalışmışlardır. Alman uyruğundan Margot Konrat ve Avusturyalı Schweifert İzmir'de görev yapmışlardır. Avusturyalı Hilde Scromm Ankara'da çalışmıştır. Çekoslovak tebaasından Fransiska Karpeles'in görev yeri belirtilmemiştir.

Bu döneme ait belgelerden ilki olan 13 Ocak 1939 tarihli olan Fransiska Karpeles hakkındaki belge ile sonuncusu olan 2 Şubat 1950 tarihli Hedwig Pfannes ile ilgili belge seçilen örnek arşiv belgeleri olarak aşağıda verilmiştir. (Şekil 3 ve 4) 
T. C.

B A SVEKALET

KARARLAR DAIRESI MUDERLUGU

Karar sayist

10.255
Kararname

Yekoslovak tebaasından ve Yahudi milletinden hasta baklcl hemşire Fransıska Karpeles' in iki sene middetle ve Alman tebaasından ve Yahudi Irkבndan dekorasyon mütehassisl Alfret Katza'nzn da I3/IO/938 tarihinden itibaren çalı şmak üzere karısı Gertrut Katza ile birlikte bir sene middetle Yurdumuzda oturmalarına izin verilmesi; Dahiliye Vekilliginin 5/I/939 taxih ve 845,846 saylla tez kerelerile yapzlan teklifleri üzerine Icra Vekilleri Heyetince I3/T; 939 tarihinde onanmistır.

I3/I/939

REISICỦHHUR

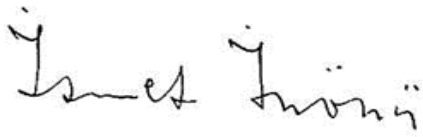

Bș. V.

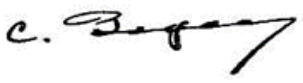

Ha. V.

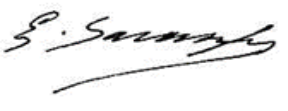

Ik. V. Prackis
Ad. V.

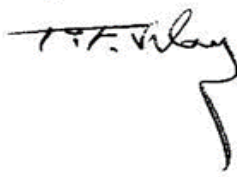
Ma. vigial.

S. 1. M. V.

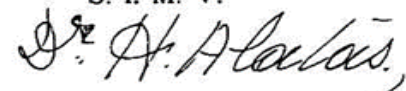

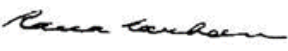

G. I. V.

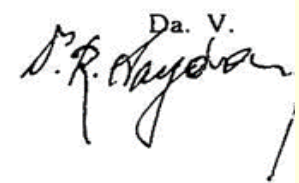

Mf. V.

Na. V.

A. Catuliowgy

Zr. V.<smiles>CCOC</smiles>

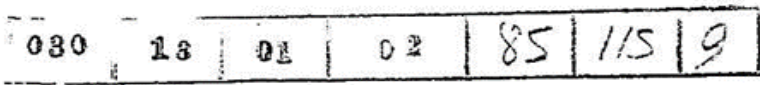

Şekil 3. 13 Ocak 1939 tarihli olan Fransiska Karpeles hakkındaki belge 


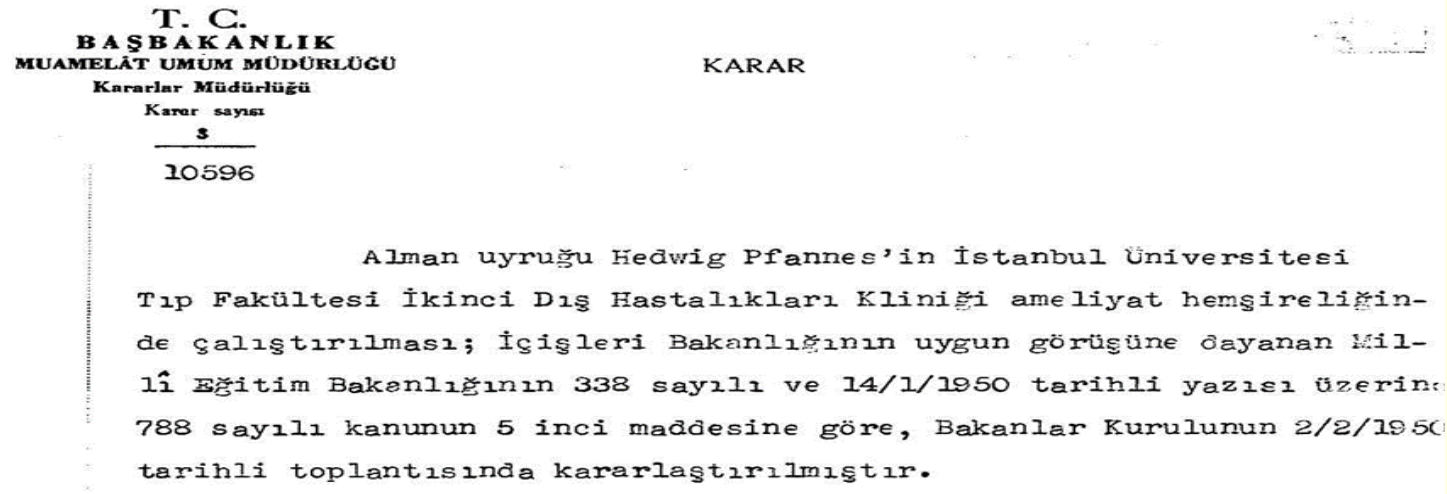

CURITURBASKANI

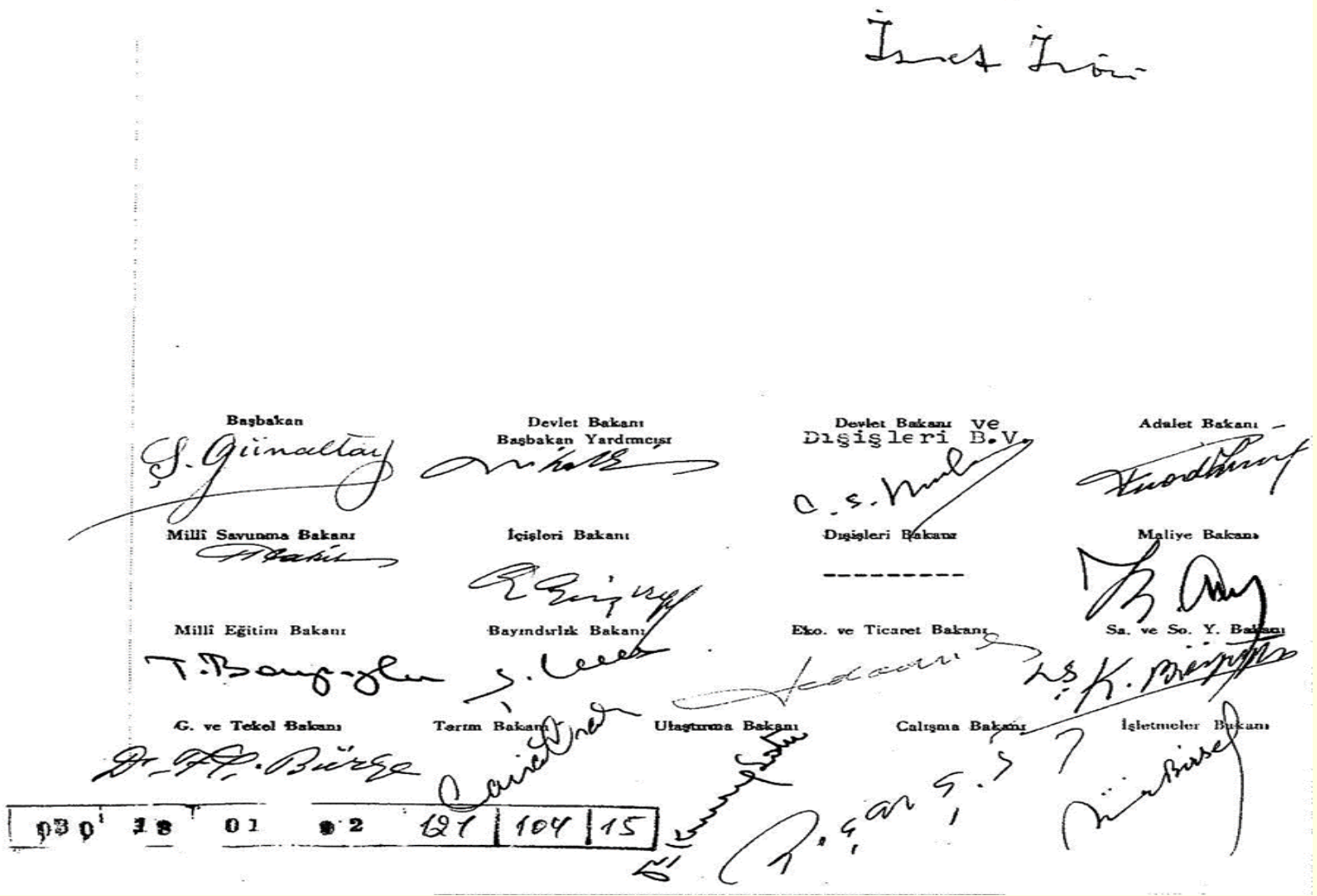

Şekil 4.2 Şubat 1950 tarihli Hedwig Pfannes ile ilgili belge

\section{Celal Bayar Döneminde Yabancı Hemşireler}

Türkiye Cumhuriyeti Cumhurbaşkanlığı Devlet Arşivleri Başkanlığı Cumhuriyet Arşivi'nde yabancı hemşirelerle ilgili Celal Bayar tarafından onaylanmış yedi belge bulunmaktadır. Bunlardan birincisi 15 Haziran 1951 tarihlidir. Buna göre Amerikalı Frances Bavons iÜ Tıp Fakültesi Birinci Dış Hastalıkları Kliniği Nöroşirürji Servisinde görev yapmıştır. ${ }^{45}$

22 Şubat 1952 tarihli arşiv belgesine göre ise Avusturya'lı hemşire Schweifert 25 Mayıs 1951 tarihinden itibaren iki yıl süreyle İstanbul Validebağ Verem Hastanesinde çalışmışır. Buna göre zaten yaklaşık dokuz aydır İstanbul Validebağ Hastanesi'nde çalışmakta olan Schweifert'in 1953 yılına kadar burada çalışması kararlaştırılmıştır. ${ }^{46}$ Daha önce 25 Mayıs 1948 tarihli bir belgeye göre Avusturyalı bir hemşire olan Schweifert'in İzmir Doktor Behçet Uz Hastanesinde 25 Mayıs 1951 tarihine kadar çalıştığından bahsedilmişti. Her ne kadar belgelerde sadece Schweifert soy ismi geçmiş, isim belirtilmemişse de 
belgelerde geçen kişinin aslında aynı kişi olduğu anlaşılmaktadır. Schweifert önce İzmir'de sonra da İstanbul'da çalışmıştır.

2 Haziran 1948'den itibaren Heybeliada Verem Sanatoryumunda başhemşire olarak çalışmaya başlayan Avusturyalı Katerina Thetter'in görev süresi 5 Mayıs 1952 tarihli Kararname ile 30 Eylül 1952'ye ${ }^{47} 25$ Aralık 1952 tarihli bir başka Kararname ile 28 Şubat $1955^{\prime} e^{48}$ ve 27 Aralık 1958 tarihli Kararname ile de 28 Şubat 1960 tarihine kadar uzatılmıştır. ${ }^{49}$

5 Mayıs 1953 tarihli arşiv belgesi Alman uyruğundan Margot Henkel ile ilgilidir. Buna göre Margot Henkel'in vazifeye başladığı tarihten itibaren iki yıl süreyle hastane veya sağıı ve sosyal yardım kurullarında çalıştırılmasına müsaade edilmiştir. ${ }^{50}$

Celal Bayar onaylı son belge ise Rosa Dotosch ile ilgilidir. 5 Ekim 1953 tarihli belgeden Avusturya tebaasından olan Dotosch'un Türkiye Cumhuriyeti Devlet Demiryolları (TCDD) işsletmesinin Sivas'taki hastanesine başhemşire olarak atandığı görülmüştür. Maaşı aylık net 400 Lira olarak belirlenmiştir. Sözleşme süresi ise iki yıldır. ${ }^{51}$ Aynı belgede ismi geçen ve hakkındaki hükmün kaldırıldığı belirtilen Fon Groller'in ne iş yaptığı belirtilmemiştir.

Bu dönemde Amerikalı Frances Bavons ile Avusturyalı hemşireler Schweifert ve Katerina Thetter İstanbul'da, Rosa Dotosch Sivas'ta çalışmıştır. Alman Margot Henkel'in görev yeri belirtilmemiştir.

Celal Bayar tarafından onaylanan belgelerden 5 Ekim 1953 tarihli Rosa Dotosch ile ilgili belge seçilen örnek arşiv belgesi olarak aşağıda verilmiştir.(Şekil 5)

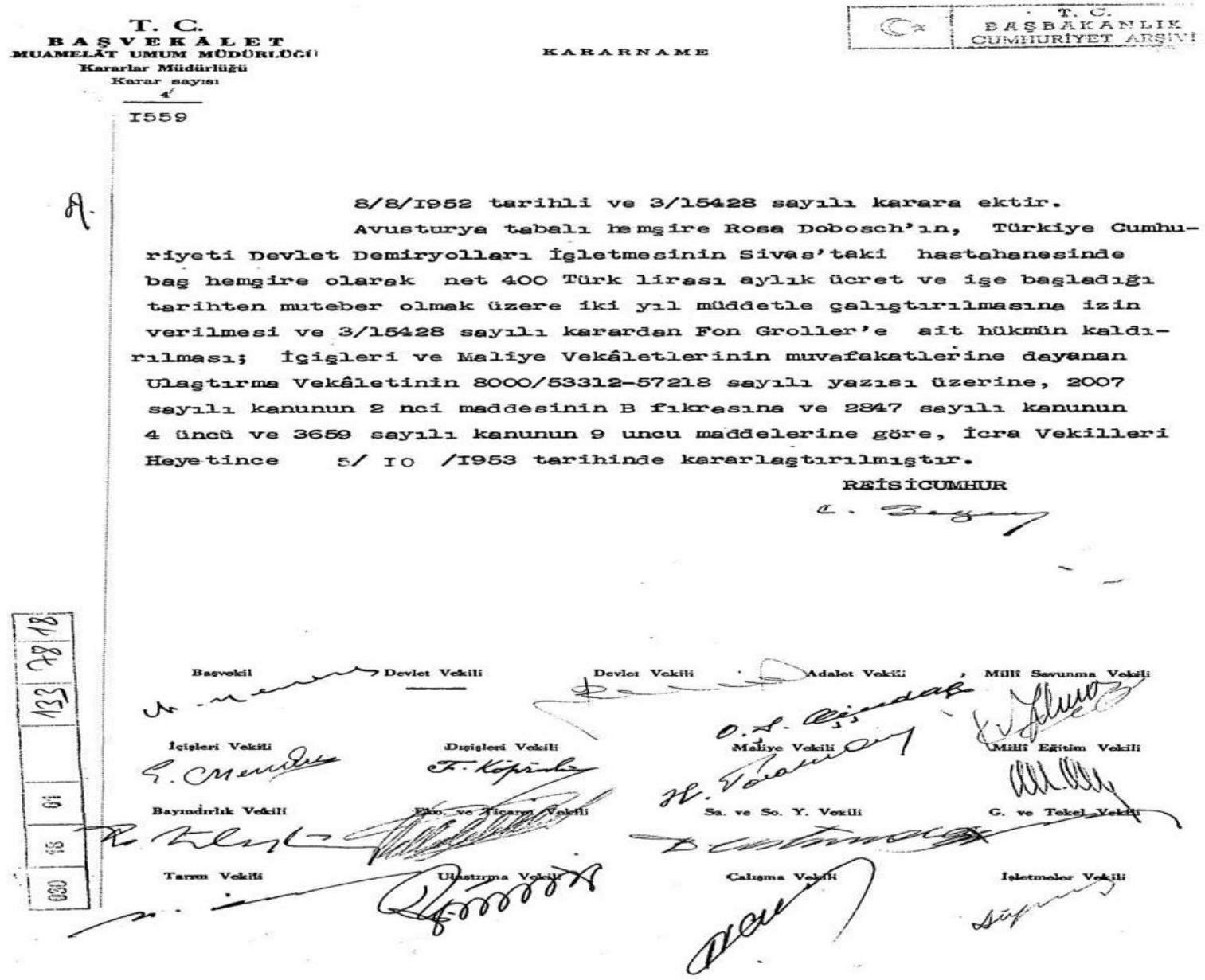

Şekil 5.5 Ekim 1953 tarihli RosaDotosch ile ilgili belge 


\section{Cemal Gürsel Tarafından Onaylanmış Belgelerde Yabancı Hemşireler}

Türkiye Cumhuriyeti Cumhurbaşkanlığı Devlet Arşivleri Başkanlığı Cumhuriyet Arşivi'nde Devlet Başkanı ve Cumhurbaşkanı unvanıyla Cemal Gürsel tarafından onaylanan belgelerin sayısı üç olarak tespit edilmiştir. 7 Eylül 1960 tarihli Kararname ile 2 Haziran 1948'den beri Heybeliada Verem Sanatoryumunda başhemşire olarak görev yapan Avusturyalı Katerina Thetter'in süresi altı ay daha uzatılmıştır. ${ }^{52}$

31 Mart 1961 tarihli bir başka arşiv belgesi ise Karin Duve ile ilgilidir. Alman tebaasından olan bu hemşirenin iÜ Tıp Fakültesi Çocuk Cerrahisi ve Ortopedi Kliniği uzman hemşiresi olarak çalışması kararlaştırılmıştır. ${ }^{53}$

Yabancı hemşirelerle ilgili Cumhuriyet Arşivinde bulunan son belge 11 Ekim 1962 tarihli olup, buna göre Clara Anna Engle isimli Amerikalı hemşirenin Ege Üniversitesi Tıp Fakültesi Yüksek Hemşire ve Sağlık Teknisyeni Okulunda çalıştırılmasına karar verilmiştir. ${ }^{54}$

Bu dönemde Avusturyalı Katerina Thetter ve Alman Karin Duve İstanbul'da, Amerikalı Clara Anna Engle ise İzmir'de çalışan yabancı hemşireler olmuşlardır.

Clara Anna Engle hakkındaki belge Cemal Gürsel tarafından onaylanan belgeler arasından örnek belge olarak seçilmiş ve aşağıda verilmiştir. (Şekil 6)

T. C.

BASBAKANLIK

KANUNLAR VE KararLaT

Tetkik Dairesi

KARARNARE

$\frac{6}{1024}$
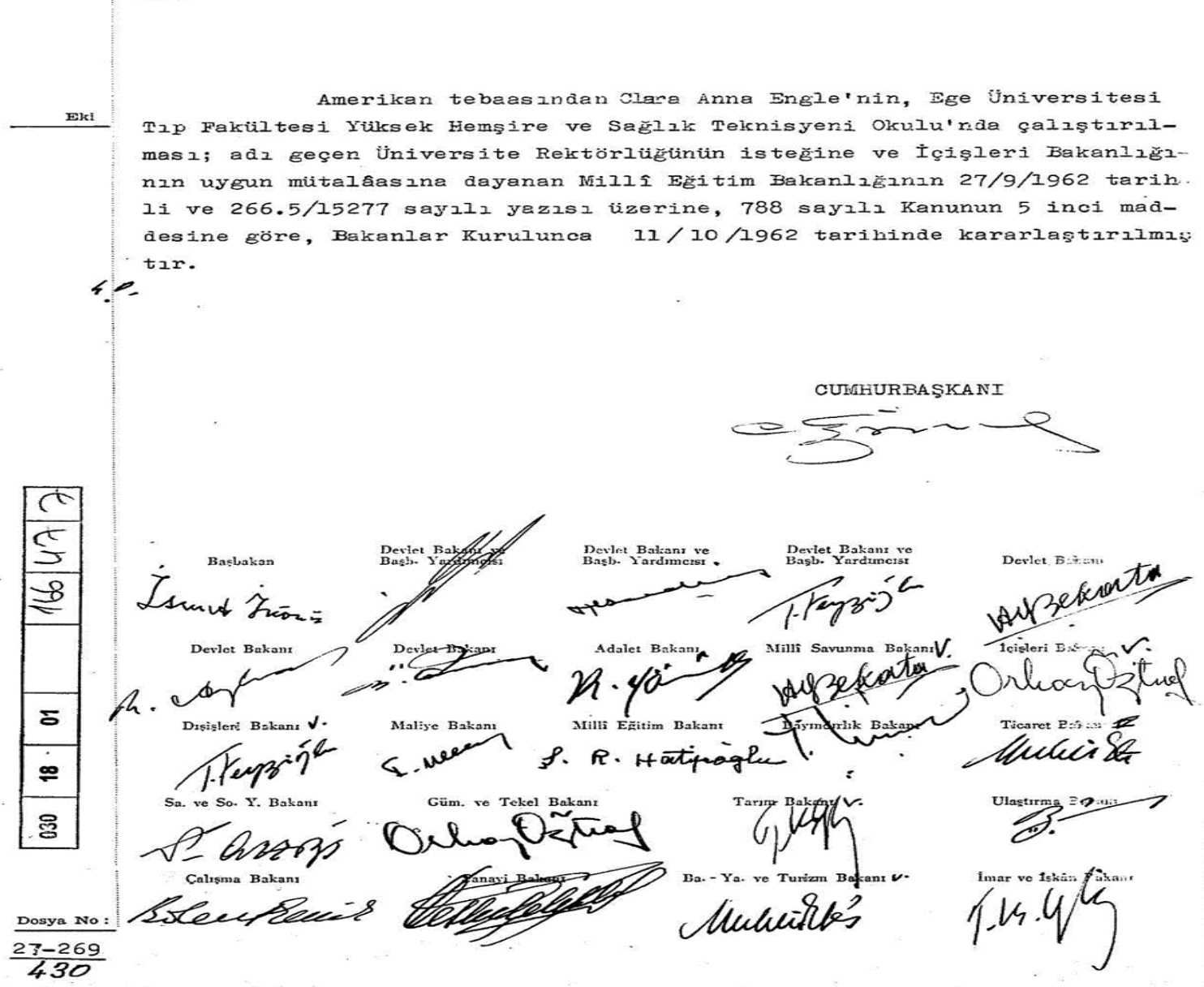

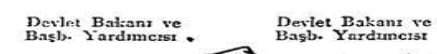

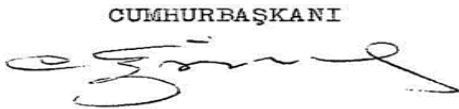

Güm. ve Tekel Baka
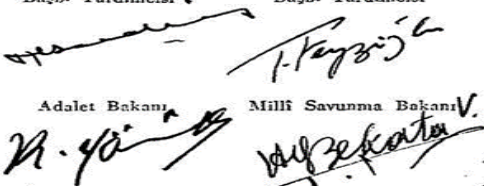

1cieleri s.

,

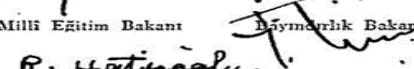

R. Hatifägle :

Colue trangef

Gifing

$\prod^{2}$

Ba. - Ya. ve Turźm Bafani $\boldsymbol{v}$ -

Aubuites
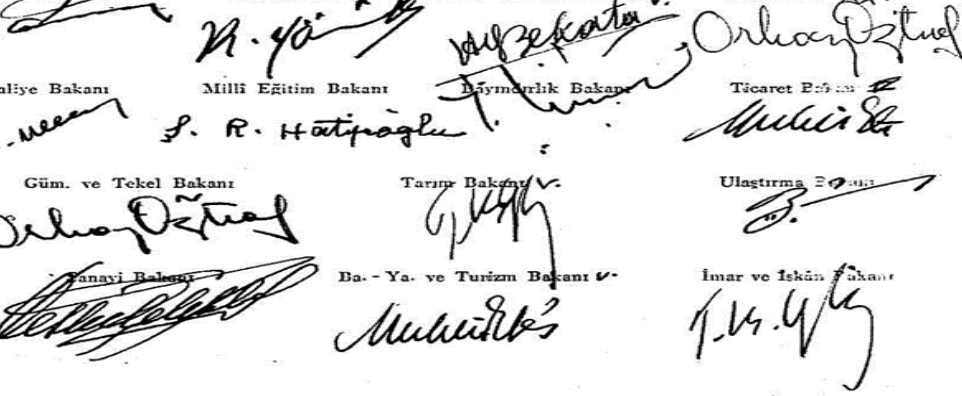

Şekil 6. 11 Ekim 1962 tarihli Clara Anna Engle ile ilgili belge 


\section{Sonuç}

Türkiye Cumhuriyeti Cumhurbaşkanlığı Devlet Arşivleri Başkanlığı Cumhuriyet Arşivinde bulunan, ilki 1931, sonuncusu da 1962 tarihli olan ve yabancı hemşire görevlendirmeleri ile ilgili toplam 36 adet belgenin incelenmesi sonucunda buralarda 26 hemşirenin isminin geçtiği, bunların çalışmalarına ilişkin hususların Kararnamelerle düzenlendiği görülmüştür.

Mevzuat gereği yabancı uyrukluların Türkiye'de çalışmaları ancak izinle mümkün olabilmektedir. Belgelerin incelendiği 31 yıllık süreçte de Türkiye'de kimlerin, ne kadar süre ve hangi görevlerde çalışacaklarına ilişkin düzenlemeler yapılmıştır.

Almanya, Avusturya, ABD, Çekoslovakya ve Polonya vatandaşı olan yabancı hemşireler Türkiye'de hemşire, uzman hemşire, başhemşire, okul yöneticisi ve öğretmen görevlerinde bulunmuşlardır. Yabancı hemşirelerin Türk hemşireliğinin kuruluşunda, hemşire eğitiminde ve hemşirelik mesleğinin gelişiminde dolaylı katkıları olmuştur.

\section{Bilgi}

T.C. Cumhurbaşkanlığı Devlet Arşivleri Başkanlığı Cumhuriyet Arşivi, çalışmanın kaynaklar kısmında BCA şeklinde yazılmıştır. Belgelere ait yer bilgileri (fon, kutu, gömlek, sıra) ve belge tarihleri yan yana verilmiştir. Çıkar çatışması bulunmamaktadır. Yazar Almanya Federal Cumhuriyeti'nin Ankara'daki Büyükelçiliği aracılığıyla kendisiyle irtibat kuran ve çalışma hakkında yönlendirmelerde bulunan Sayın Regine Erichsen'e teşekkür eder.

\section{Kaynaklar}

1. Güney Kızıl E., ve ark. Hemşirelerin Görevlerini Bilme, Benimseme ve Yerine Getirme Durumları: İzmir Örneği. Hemşirelikte Eğitim ve Araştırma Dergisi (HEAD) 2015;12(3):215-223.

2. Torun S., Öner Yalçın S., Kadıoğlu FG. Erkek Hemşirelerin Kısa Tarihi, Lokman Hekim Journal 2013, Supplement VIII., Lokman Hekim Days, 22 - 25 May 2013, Ninth Session: Poster Session, p.98.

3. Çınar D., Olgun N. Klinik Uygulamalarda Erkek Hemşire Algısı. Hemşirelikte Eğitim ve Araştırma Dergisi (HEAD) 2013;10(3):3-6.

4. Şentürk S. Hemşirelik Tarihi, İstanbul, Nobel Tıp Kitabevleri, 2011.

5. Nelson S., Rafferty AM. Giriş, Florance Nihtgingale Hakkında Düşünceler Bir Hemşirelik ikonunun Etkileri ve Mirası, Ed. Nelson S., Rafferty AM., Çev. Ed. Akyolcu N., Anğ Ö., İstanbul, Nobel Tıp Kitabevleri, 2016, s.1-9.

6. Torun S. Kırım Savaşı'nda Hasta Bakımı ve Hemşirelik, Ankara, Akademisyen Tıp Kitabevi, 2014.

7. Taşkıran N. Florance Nightingale ve Kendisine Ait Yayınlanmamış Türk Arşiv Belgeleri, Türkiye'de Hemşirelik ve Gelişimi Tarihi, Kayseri, Erciyes Üniversitesi Gevher Nesibe Tıp Tarihi Enstitüsü Yayın No:23, 1996, s.11-58.

8. Yıldırım N. Savaşlardan Modern Hastanelere Türkiye'de Hemşirelik Tarihi, İstanbul, Vehbi Koç Vakfı, 2014, s. 209-307.

9. ilikan Rasimoğlu CG. Tanzimat, Hayırseverlik ve Kadın: Filles De La Charité Rahibelerinin Osmanlı İmparatorluğu Topraklarına Gelişi ve İstanbul'daki İlk Yılları, İzmir, DEÜ Sos. Bil. Ens. Dergisi 2018;20(4):603-619.

10. Karal Akgün S., Uluğtekin M. Hilal-i Ahmer'den Kızılay’a, Ankara, Kızılay Yay., 2002.

11. Ataç A. Gülhane Askeri Tıp Akademisi'nin Kuruluşu, Ankara, Atatürk Kültür, Dil ve Tarih Yüksek Kurumu Atatürk Kültür Merkezi Yay., 1996.

12. Altay S. Atatürk Dönemi Sağlık Politikalarının Halka Yansımasında Öncü Kurumlar: Numune Hastaneleri (1924-1938), Doktora Tezi, Ankara Üniversitesi, 2015.

13. Öztürk H., Demirsoy N. Cumhuriyetin IIlk Yıllarında Ulusallaşma Çabaları ve Sağlık Alanında Yapılan Ulusallaşma Çalışmalarının Değerlendirilmesi. Türkiye Klinikleri J Med Ethics 2019;27(1):11-24.

14. Namal Y. Türkiye'de 1933-1950 Yılları Arasında Yükseköğretime Yabancı Bilim Adamlarının Katkıları, Yükseköğretim ve Bilim Dergisi 2012;2(1):14-19.

15. Türkiye İstatistik Kurumu, İstatistik Göstergeler (1923-2011), Ankara, Türkiye İstatistik Kurumu Matbaası, 2012, s.51-62.

16. BCA. 30-18-1-2 / $17-7-15,1 / 2 / 1931$.

17. BCA. 30-18-1-2 / $17-7-18,1 / 2 / 1931$.

18. BCA. 30-18-1-2 / 18 - $19-3,18 / 3 / 1931$.

19. BCA. 30-18-1-2 / 20 - $31-7,18 / 5 / 1931$.

20. BCA. 30-18-1-2 / $36-39-8,23 / 5 / 1933$.

21. BCA. 30-18-1-2 / 20 - 39-8, 7/6/1931. 
22. BCA. 30-18-1-2 / $23-64-18,14 / 9 / 1931$.

23. BCA. 30-18-1-2 / $26-12-16,2 / 3 / 1932$.

24. Gürgan M., Ulus T. İstanbul Heybeliada Sanatoryumu, 2020, Erişim adresi: http://www.sdplatform.com/Dergi/495/IstanbulHeybeliada-Sanatoryumu.aspx (Internet)

25. BCA. 30-18-1-2 / 31 - $65-2,9 / 10 / 1932$.

26. BCA. 30-18-1-2 / $48-69-10,11 / 10 / 1934$.

27. BCA. 30-18-1-2 / 70 - $99-8,4 / 1 / 1937$.

28. BCA. 30-18-1-2 / 51 - 1 - 20, 1/1/1935.

29. BCA. 30-18-1-2 / 64 - $39-3,13 / 5 / 1936$.

30. Tosun H. İstanbul'da Kurulan Cumhuriyetin İlk Milli Hemşirelik Okulu “Kızılay Hemşirelik Lisesi”, Maltepe Üniversitesi Hemşirelik Bilim ve Sanatı Dergisi, Sempozyum Özel Sayısı, 2010, s.126-130.

31. BCA. 30-18-1-2 / $85-115-9,13 / 1 / 1939$.

32. BCA. 30-18-1-2 / $87-58-16,22 / 6 / 1939$.

33. Seyhun G., II. Dünya Savaşında Türkiye'de Gönüllü Hemşirelik Kursları. İstanbul Üniversitesi Kadın Araştırmaları Dergisi 2018;I:730.

34. BCA. 30-18-1-2 / $88-82-1,25 / 8 / 1939$.

35. BCA. 30-18-1-2 / $90-19-10,4 / 3 / 1940$.

36. BCA. 30-18-1-2 / 92 - $95-3$, 28/9/1940.

37. BCA. 30-18-1-2 / $100-94-5,16 / 11 / 1942$.

38. BCA. 30-18-1-2 / $107-87-10,14 / 12 / 1944$.

39. BCA. 30-18-1-2 / 113 - 31 - 9, 5/5/1947.

40. BCA. 30-18-1-2 / 116 - $35-19$, 25/5/1948.

41. BCA. 30-18-1-2/116 - $38-2,2 / 6 / 1948$.

42. BCA. 30-18-1-2 / 119 - $28-17$, 18/4/1949.

43. BCA. 30-18-1-2 / 120 - 72 - 18, 13/10/1949.

44. BCA. 30-18-1-2 / 121 - $104-15$, 2/2/1950.

45. BCA. 30-18-1-2 / $126-47-19,15 / 6 / 1951$.

46. BCA. 30-18-1-2 / $128-15-7,22 / 2 / 1952$.

47.BCA. 30-18-1-2 / 129 - $37-8,5 / 5 / 1952$.

48. BCA. 30-18-1-2 / $130-94-4,25 / 12 / 1952$.

49. BCA. 30-18-1-2 / $151-66-4,27 / 12 / 1958$.

50. BCA. 30-18-1-2 / 132 - $38-14,5 / 5 / 1953$.

51. BCA. 30-18-1-2 / $133-78-18,5 / 10 / 1953$.

52. BCA. 30-18-1-2 / $156-16-3,7 / 9 / 1960$.

53. BCA. 30-18-1-2 / $159-16-1,31 / 3 / 1961$.

54. BCA. 30-18-1-2 / 166 - $47-7,11 / 10 / 1962$. 